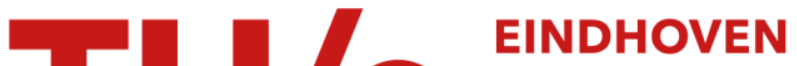 UNIVERSITY OF TECHNOLOGY
}

\section{Evidence of nanostructuration from the heat capacities of the 1,3-dialkylimidazolium bis(trifluoromethylsulfonyl)imide ionic liquid}

\section{Citation for published version (APA):}

Alves da Rocha, M. A., Coutinho, J. A. P., \& Santos, L. M. N. B. F. (2013). Evidence of nanostructuration from the heat capacities of the 1,3-dialkylimidazolium bis(trifluoromethylsulfonyl)imide ionic liquid. Journal of Chemical Physics, 139, 104502-1/6. https://doi.org/10.1063/1.4820825

DOI:

$10.1063 / 1.4820825$

Document status and date:

Published: 01/01/2013

\section{Document Version:}

Publisher's PDF, also known as Version of Record (includes final page, issue and volume numbers)

\section{Please check the document version of this publication:}

- A submitted manuscript is the version of the article upon submission and before peer-review. There can be important differences between the submitted version and the official published version of record. People interested in the research are advised to contact the author for the final version of the publication, or visit the DOI to the publisher's website.

- The final author version and the galley proof are versions of the publication after peer review.

- The final published version features the final layout of the paper including the volume, issue and page numbers.

Link to publication

\footnotetext{
General rights

- You may freely distribute the URL identifying the publication in the public portal. follow below link for the End User Agreement:

www.tue.nl/taverne

Take down policy

If you believe that this document breaches copyright please contact us at:

openaccess@tue.nl

providing details and we will investigate your claim.
}

Copyright and moral rights for the publications made accessible in the public portal are retained by the authors and/or other copyright owners and it is a condition of accessing publications that users recognise and abide by the legal requirements associated with these rights.

- Users may download and print one copy of any publication from the public portal for the purpose of private study or research.

- You may not further distribute the material or use it for any profit-making activity or commercial gain

If the publication is distributed under the terms of Article 25fa of the Dutch Copyright Act, indicated by the "Taverne" license above, please 


\section{AD $\mid \begin{aligned} & \text { The Journal of } \\ & \text { Chemical Physics }\end{aligned}$}

Evidence of nanostructuration from the heat capacities of the 1,3-dialkylimidazolium bis(trifluoromethylsulfonyl)imide ionic liquid series

Marisa A. A. Rocha, João A. P. Coutinho, and Luís M. N. B. F. Santos

Citation: The Journal of Chemical Physics 139, 104502 (2013); doi: 10.1063/1.4820825

View online: http://dx.doi.org/10.1063/1.4820825

View Table of Contents: http://scitation.aip.org/content/aip/journal/jcp/139/10?ver=pdfcov

Published by the AIP Publishing

\section{Articles you may be interested in}

Vapor pressures of 1,3-dialkylimidazolium bis(trifluoromethylsulfonyl)imide ionic liquids with long alkyl chains J. Chem. Phys. 141, 134502 (2014); 10.1063/1.4896704

Modeling of solubility of $\mathrm{CO} 2$ in 1-butylpyridinium bis(trifluoromethylsulfonyl)imide ionic liquid using UNIFAC AIP Conf. Proc. 1482, 229 (2012); 10.1063/1.4757471

Heat Capacity of Liquids: Critical Review and Recommended Values. Supplement II

J. Phys. Chem. Ref. Data 39, 013103 (2010); 10.1063/1.3182831

Comparative study of electron stimulated positive-ion desorption from $\mathrm{LiCl}$ and 1-ethyl-3-methylimidazolium bis[trifluoromethylsulfonyl]imide

J. Chem. Phys. 131, 084702 (2009); 10.1063/1.3212563

Erratum: "Heat Capacity of Liquids. Critical Review and Recommended Values. Volumes I and II." [J. Phys. Chem. Ref. Data, Monograph No. 6 (1996)]

J. Phys. Chem. Ref. Data 30, 441 (2001); 10.1063/1.1358838

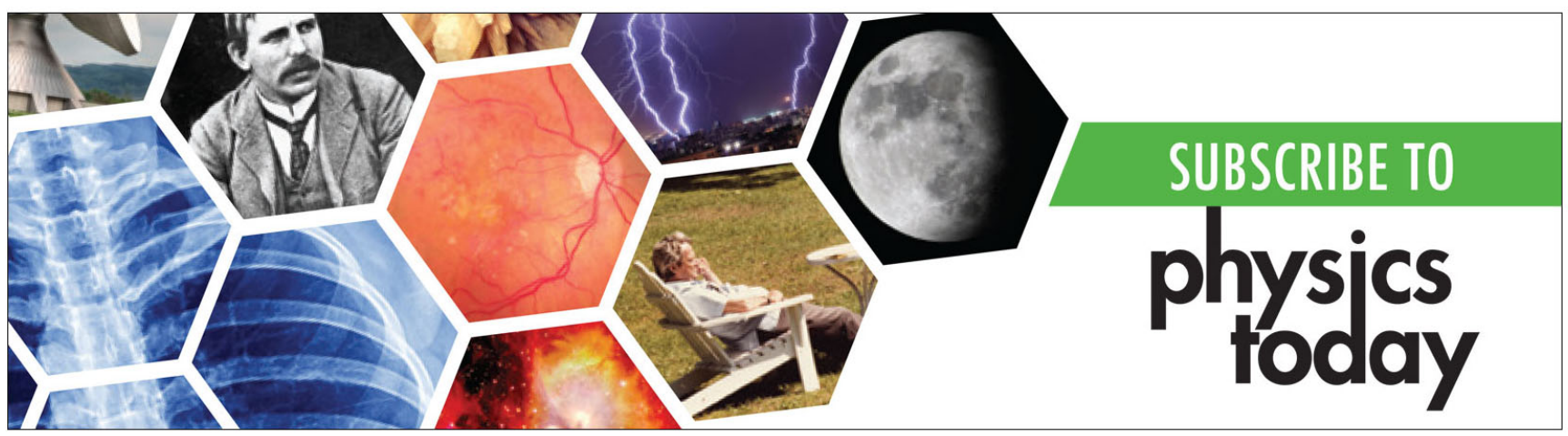




\title{
Evidence of nanostructuration from the heat capacities of the 1,3-dialkylimidazolium bis(trifluoromethylsulfonyl)imide ionic liquid series
}

\author{
Marisa A. A. Rocha, ${ }^{1, a)}$ João A. P. Coutinho, ${ }^{2}$ and Luís M. N. B. F. Santos ${ }^{1, a)}$ \\ ${ }^{1}$ Centro de Investigação em Química, Departamento de Química e Bioquímica, Faculdade de Ciências, \\ Universidade do Porto, Rua do Campo Alegre, 687, P-4169-007 Porto, Portugal \\ ${ }^{2}$ CICECO, Departamento de Química, Universidade de Aveiro, P-3810-193 Aveiro, Portugal
}

(Received 29 May 2013; accepted 26 August 2013; published online 12 September 2013)

\begin{abstract}
In the present work, the heat capacities at $T=298.15 \mathrm{~K}$ of 1,3-dialkylimidazolium bis(trifluoromethylsulfonyl)imide, $\left[\mathrm{C}_{\mathrm{N} / 2} \mathrm{C}_{\mathrm{N} / 2} \mathrm{im}\right]\left[\mathrm{NTf}_{2}\right]$, were measured, for the first time, using a high-precision heat capacity drop calorimeter, with an uncertainty of less than $0.15 \%$. Based on the obtained results, it was possible to evaluate the effect of the cation symmetry on the heat capacity data through a comparative analysis with the $\left[\mathrm{C}_{\mathrm{N}-1} \mathrm{C}_{1} \mathrm{im}\right]\left[\mathrm{NTf}_{2}\right]$ ionic liquid series. The molar heat capacities of the $\left[\mathrm{C}_{\mathrm{N} / 2} \mathrm{C}_{\mathrm{N} / 2} \mathrm{im}\right]\left[\mathrm{NTf}_{2}\right]$ ionic liquids series present a less pronounced deviation from the linearity along the alkyl chain length than the asymmetric based ionic liquids series. Lower molar heat capacities for the symmetric than the asymmetric series were observed, being this difference more evident for the specific and volumic heat capacities. As observed for the $\left[\mathrm{C}_{\mathrm{N}-1} \mathrm{C}_{1} \mathrm{im}\right]\left[\mathrm{NTf}_{2}\right]$ series, a trend shift in the heat capacities at $\left[\mathrm{C}_{6} \mathrm{C}_{6} \mathrm{im}\right]\left[\mathrm{NTf}_{2}\right]$ was found that reflects the impact of nonpolar region nanostructuration on the thermophysical properties of the ionic liquids. The profile of the two regions is in agreement with the expected effect arising from the nanostructuration in ionic liquids. The results obtained in the present work show a clear indication that for the symmetric series, $\left[\mathrm{C}_{\mathrm{N} / 2} \mathrm{C}_{\mathrm{N} / 2} \mathrm{im}\right]\left[\mathrm{NTf}_{2}\right]$, the starting of the liquid phase nanostructuration/alkyl chain segregation occurs around $\left[\mathrm{C}_{6} \mathrm{C}_{6} \mathrm{im}\right]\left[\mathrm{NTf}_{2}\right]$. @ 2013 AIP Publishing LLC. [http://dx.doi.org/10.1063/1.4820825]
\end{abstract}

\section{INTRODUCTION}

Heat capacity is one of the most important thermophysical properties characterizing the liquid phase, and is intimately linked to the temperature dependence of fundamental thermodynamic properties. Heat capacities are essential for the temperature correction of entropy and enthalpy in any chemical or physical process, it can be used to evaluate molecular and supramolecular interactions, as well as, highlight some structural and dynamics properties of materials. Accurate heat capacity data have a wide field of application in thermochemistry for calculating changes in reaction enthalpies and in chemical engineering for establishing energy balances. ${ }^{1-3}$ The possible use of ionic liquids (ILs) as heat transfer for heat exchange in chemical plants and solar thermal power generation was discussed, and it was found that the imidazolium based ionic liquids present higher heat capacities per unit of volume that two high performance commercial thermal fluids. ${ }^{4-6}$ The knowledge of the heat capacity is required for the evaluation of the applicability of the ionic liquids as heat transfer fluids. ${ }^{4-6}$

During the past decade, the research in ionic liquids has gained popularity, mainly due to their particular properties. Hence, intense research in these systems was performed both in fundamental and applied fields, contributing to the progress in the understanding of the ionic liquids at a molecular level,

\footnotetext{
a) Authors to whom correspondence should be addressed. Electronic addresses: marisa.alexandra.rocha@gmail.com and lbsantos@fc.up.pt. Tel.: +351220402 836. Fax: +351220402659
}

and consequently, to the advance in the applied field..$^{7-9}$ The comprehension of the physical chemical properties of ionic liquids and their adequate tuning, relies on the adequate understanding of the molecular structure of the ILs in the liquid phase. The structural organization of the liquid phase of ionic liquids comprises high charge density organized themselves in order to satisfy the electroneutrality conditions and to enhance the electrostatic interactions between the cation and anion, and the alkyl chains of the cation (low charge density) segregate elsewhere. ${ }^{10-14}$ The interaction between these two types of regions (polar and nonpolar) led to the recognition of ionic liquids as high-charge density (polar) network permeated by low-charge density (non-polar) regions. ${ }^{10-14}$ This characteristic of the structural organization in ionic liquids was later supported experimentally by X-ray diffraction ${ }^{15}$ and by small-wide angle X-ray scattering (SWAXS). ${ }^{16,17}$ Recently, the studies exploring mesoscopic structural heterogeneities in ionic liquids has been compiled and discussed in order to give a better understanding on the nature of structural heterogeneities in ILs. ${ }^{18}$ Shimizu et al.,${ }^{19}$ based on molecular dynamics simulation, have shown that the structural segregation in ILs depends on the size of the polar and nonpolar regions. These regions can exist as isolated (dispersed) islands or a second continuous phase, in which the transition from a dispersed to a continuous non-polar phase corresponds to the nanostructuration limit. ${ }^{19}$ Recently we have reported the heat capacities at $T=298.15 \mathrm{~K}$ of the extended series of ionic liquids, $\left[\mathrm{C}_{\mathrm{N}-1} \mathrm{C}_{1} \mathrm{im}\right]\left[\mathrm{NTf}_{2}\right]$ (with $\mathrm{N}=3-9,11$, and 13), where the effect of the nanostructuration of ionic liquids in 
this property was evaluated. ${ }^{20}$ In this work a trend shift along the alkyl side chain length, related to a change in the molecular structure of the liquid phase around $\left[\mathrm{C}_{6} \mathrm{C}_{1} \mathrm{im}\right]\left[\mathrm{NTf}_{2}\right]$, in agreement with the thermodynamic study of vaporization published, for the same ionic liquid family ${ }^{21}$ was disclosed. It was also shown that the effect of the nanostructuration is more visible when the heat capacities and enthalpies of vaporization on a volumetric basis are used. This being a result of the relationship of the trend shift with the cohesive energy of the liquid. ${ }^{20}$

In the present work, the heat capacities at $T=298.15 \mathrm{~K}$ of 1,3-dialkylimidazolium bis(trifluoromethylsulfonyl)imide, $\left[\mathrm{C}_{\mathrm{N} / 2} \mathrm{C}_{\mathrm{N} / 2} \mathrm{im}\right]\left[\mathrm{NTf}_{2}\right]$, were measured using a high-precision heat capacity drop calorimeter developed by Wadsö ${ }^{22,23}$ and recently updated in our laboratory. ${ }^{24}$ This work complements and extends the previous study concerning the heat capacities of the $\left[\mathrm{C}_{\mathrm{N}-1} \mathrm{C}_{1} \mathrm{im}\right]\left[\mathrm{NTf}_{2}\right]$ ionic liquid series, aiming at evaluating the effect of the symmetry and nanostructuration on the heat capacities of an ionic liquid homologous series.

\section{EXPERIMENTAL DETAILS}

The 1,3-dialkylimidazolium bis(trifluoromethylsulfonyl)imide series, $\left[\mathrm{C}_{\mathrm{N} / 2} \mathrm{C}_{\mathrm{N} / 2} \mathrm{im}\right]\left[\mathrm{NTf}_{2}\right](\mathrm{N}=2,4,6,8,10,12$, $14,16,18,20)$, used in this work, were purchased from IOLITEC with a stated purity of better than $98 \%$. All ionic liquids were dried under reduced pressure $(<10 \mathrm{~Pa})$ and stirred constantly at $323 \mathrm{~K}$, in order to reduce the presence of water or other volatile contents. This process was performed systematically before and during the heat capacity measurements. The purity of each ionic liquid was further evaluated by ${ }^{1} \mathrm{H},{ }^{13} \mathrm{C}$, and ${ }^{19} \mathrm{~F}$ NMR spectra and all ionic liquids found to be $>99$ wt. $\%$ purity. The water contents of the degassed samples were determined with a Metrohm 737 Karl Fischer coulometer, using the Hydranal ${ }^{\circledR}$ - Coulomat AG from Riedelde Haën, and revealed less than 200 ppm of water.

\section{A. High-precision heat capacity drop calorimetry}

The heat capacities at $T=298.15 \mathrm{~K}$ of the extended series of $\left[\mathrm{C}_{\mathrm{N} / 2} \mathrm{C}_{\mathrm{N} / 2} \mathrm{im}\right]\left[\mathrm{NTf}_{2}\right](\mathrm{N}=2,4,6,8,10,12,14,16$, $18,20)$ ionic liquids were measured by a high-precision heat capacity drop calorimeter, which is described in detail in the literature. ${ }^{22-24}$ The calorimeter, was originally developed and used at the Thermochemistry Laboratory, Lund, Sweden, ${ }^{22,23}$ being afterwards transferred to Porto, Portugal, where it was reassembled, modernized, and tested. ${ }^{24}$ The apparatus comprises two main parts: the furnace and the calorimetric receiving block. The furnace is maintained at a constant temperature $T=303.15 \mathrm{~K}$ and the receiving calorimeter is kept at $T=293.15 \mathrm{~K}$. The ampoules were weighted in a Mettler Toledo AG245 dual range analytical balance (sensitivity of $0.00001 \mathrm{~g}$ and repeatability of $0.00002 \mathrm{~g}$ ) both empty and after filling with the ionic liquid. The ampoule was maintained in the furnace for temperature equilibration, in a fixed position, by means of a drop and lift mechanism system. After a pre-defined time, the ampoule was dropped into the receiving calorimetric block at a well-defined temperature, and was kept there for a fixed time interval. In each independent drop experiment, the drop procedure was automatically repeated using the same experimental conditions, used for the blanks and calibration experiments. In the present work the apparatus was used in single-drop mode (no reference ampoule was used) with blank correction that was measured independently using empty ampoules.

The calorimeter was calibrated with water and sapphire $\left(\alpha-\mathrm{Al}_{2} \mathrm{O}_{3}\right.$ ), using the respective standard molar heat capacities at $298.15 \mathrm{~K}$ reported in literature, $C_{p, m}^{o}\left(\mathrm{H}_{2} \mathrm{O}\right)=(75.32$ $\pm 0.01) \mathrm{J} \mathrm{K}^{-1} \mathrm{~mol}^{-1}$ and $C_{p, m}^{o}(\alpha$-aluminum oxide $)=(79.03$ $\pm 0.08) \mathrm{J} \mathrm{K}^{-1} \mathrm{~mol}^{-1}{ }^{25}$ The calibration constant was found to be $\varepsilon=(6.6040 \pm 0.0036) \mathrm{W} \mathrm{V}^{-1}$. Since the calorimeter was used to measure the heat capacity of ionic liquids, the accuracy was checked on the basis of the results obtained for $\left[\mathrm{C}_{6} \mathrm{C}_{1} \mathrm{im}\right]\left[\mathrm{NTf}_{2}\right]$. The determined $C_{p, m}^{o}\left(\left[\mathrm{C}_{6} \mathrm{C}_{1} \mathrm{im}\right]\left[\mathrm{NTf}_{2}\right]\right.$, $298.15 \mathrm{~K})=(629.24 \pm 0.43) \mathrm{J} \mathrm{K}^{-1} \mathrm{~mol}^{-1}$ was obtained from the average of two independent experiments, using different ampoules, and is in excellent agreement with the recommended value, $C_{p, m}^{o}\left(\left[\mathrm{C}_{6} \mathrm{C}_{1} \mathrm{im}\right]\left[\mathrm{NTf}_{2}\right], 298.15 \mathrm{~K}\right)=(631.6$ $\pm 1.3) \mathrm{J} \mathrm{K}^{-1} \mathrm{~mol}^{-1} .^{26}$

The relative atomic masses of the 11 elements have been presented as an interval, in the latest IUPAC technical report 2009. ${ }^{27}$ Since the values reported in the IUPAC Commission in $2007^{28}$ are within the presented interval, we choose to use the relative atomic masses recommended by the IUPAC report 2007 in this work. ${ }^{28}$ All the uncertainties are given as twice of the standard deviation of the mean, and include the calibration uncertainty. The buoyancy effect correction was considered both for the calibration and experiments of the ionic liquids.

\section{RESULTS AND DISCUSSION}

The molar masses, $M\left(\mathrm{~g} \mathrm{~mol}^{-1}\right)$, number of drop experiments, $N_{\text {drop }}$, and the measured molar heat capacities at $298.15 \mathrm{~K}, C_{p, m}^{o}\left(\mathrm{~J} \mathrm{~K}^{-1} \mathrm{~mol}^{-1}\right)$, for the studied ionic liquids are presented in Table I.

Table II lists a compilation of the heat capacity data for the studied ionic liquids at $T=298.15 \mathrm{~K}$. The volumic heat capacities, $C_{p}^{o} / V$, were calculated taking into account the

TABLE I. Molar heat capacity values, at $T=298.15 \mathrm{~K}$, for the studied ionic liquids.

\begin{tabular}{lccc}
\hline \hline Ionic liquid & $M\left(\mathrm{~g} \mathrm{~mol}^{-1}\right)$ & $N_{\text {drop }}$ & $C_{p, m}^{o}\left(\mathrm{~J} \mathrm{~K}^{-1} \mathrm{~mol}^{-1}\right)$ \\
\hline$\left[\mathrm{C}_{1} \mathrm{C}_{1} \mathrm{im}\right]\left[\mathrm{NTf}_{2}\right]$ & 377.286 & 14 & $472.33 \pm 0.46$ \\
{$\left[\mathrm{C}_{2} \mathrm{C}_{2} \mathrm{im}\right]\left[\mathrm{NTf}_{2}\right]$} & 405.340 & 20 & $532.64 \pm 0.52$ \\
{$\left[\mathrm{C}_{3} \mathrm{C}_{3} \mathrm{im}\right]\left[\mathrm{NTf}_{2}\right]$} & 433.393 & 16 & $594.52 \pm 0.49$ \\
{$\left[\mathrm{C}_{4} \mathrm{C}_{4} \mathrm{im}\right]\left[\mathrm{NTf}_{2}\right]$} & 461.446 & 33 & $656.79 \pm 0.82$ \\
{$\left[\mathrm{C}_{5} \mathrm{C}_{5} \mathrm{im}\right]\left[\mathrm{NTf}_{2}\right]$} & 489.500 & 17 & $718.19 \pm 0.71$ \\
{$\left[\mathrm{C}_{6} \mathrm{C}_{6} \mathrm{im}\right]\left[\mathrm{NTf}_{2}\right]$} & 517.553 & 14 & $778.50 \pm 0.77$ \\
{$\left[\mathrm{C}_{7} \mathrm{C}_{7} \mathrm{im}\right]\left[\mathrm{NTf}_{2}\right]$} & 545.606 & 23 & $838.71 \pm 0.62$ \\
{$\left[\mathrm{C}_{8} \mathrm{C}_{8} \mathrm{im}\right]\left[\mathrm{NTf}_{2}\right]$} & 573.660 & 20 & $906.36 \pm 1.23$ \\
{$\left[\mathrm{C}_{9} \mathrm{C}_{9} \mathrm{im}\right]\left[\mathrm{NTf}_{2}\right]$} & 601.713 & 15 & $966.17 \pm 1.38$ \\
{$\left[\mathrm{C}_{10} \mathrm{C}_{10} \mathrm{im}\right]\left[\mathrm{NTf}_{2}\right]$} & 629.766 & 19 & $1027.00 \pm 0.86$ \\
\hline \hline
\end{tabular}

$N_{\text {drop }}=$ Number of drop experiments; the number of drops is the sum of the drops that were obtained in two or more independent experiments. 
TABLE II. Densities, $\rho$, specific heat capacities, $c_{p}^{o}$, volumic heat capacities, $C_{p}^{o} / V$, and molar heat capacities, $C_{p, m}^{o}$, at $T=298.15 \mathrm{~K}$, for each ionic liquid.

\begin{tabular}{|c|c|c|c|c|}
\hline Ionic liquid & $\rho(298.15 \mathrm{~K})\left(\mathrm{g} \mathrm{cm}^{-3}\right)[$ Ref. 29] & $c_{p}^{o}\left(\mathrm{~J} \mathrm{~K}^{-1} \mathrm{~g}^{-1}\right)$ & $C_{p}^{o} / V\left(\mathrm{~J} \mathrm{~K}^{-1} \mathrm{~cm}^{-3}\right)^{\mathrm{a}}$ & $C_{p, m}^{o}\left(\mathrm{~J} \mathrm{~K}^{-1} \mathrm{~mol}^{-1}\right)$ \\
\hline$\left[\mathrm{C}_{1} \mathrm{C}_{1} \mathrm{im}\right]\left[\mathrm{NTf}_{2}\right]$ & 1.5692 & $1.2519 \pm 0.0012$ & $1.9645 \pm 0.0019$ & $472.33 \pm 0.46$ \\
\hline$\left[\mathrm{C}_{2} \mathrm{C}_{2} \mathrm{im}\right]\left[\mathrm{NTf}_{2}\right]$ & 1.4749 & $1.3141 \pm 0.0013$ & $1.9382 \pm 0.0019$ & $532.64 \pm 0.52$ \\
\hline$\left[\mathrm{C}_{3} \mathrm{C}_{3} \mathrm{im}\right]\left[\mathrm{NTf}_{2}\right]$ & 1.3990 & $1.3718 \pm 0.0011$ & $1.9191 \pm 0.0015$ & $594.52 \pm 0.49$ \\
\hline$\left[\mathrm{C}_{4} \mathrm{C}_{4} \mathrm{im}\right]\left[\mathrm{NTf}_{2}\right]$ & 1.3428 & $1.4233 \pm 0.0018$ & $1.9112 \pm 0.0024$ & $656.79 \pm 0.82$ \\
\hline$\left[\mathrm{C}_{5} \mathrm{C}_{5} \mathrm{im}\right]\left[\mathrm{NTf}_{2}\right]$ & 1.2924 & $1.4672 \pm 0.0015$ & $1.8962 \pm 0.0019$ & $718.19 \pm 0.71$ \\
\hline$\left[\mathrm{C}_{6} \mathrm{C}_{6} \mathrm{im}\right]\left[\mathrm{NTf}_{2}\right]$ & 1.2550 & $1.5042 \pm 0.0015$ & $1.8878 \pm 0.0019$ & $778.50 \pm 0.77$ \\
\hline$\left[\mathrm{C}_{7} \mathrm{C}_{7} \mathrm{im}\right]\left[\mathrm{NTf}_{2}\right]$ & 1.2252 & $1.5372 \pm 0.0011$ & $1.8834 \pm 0.0013$ & $838.71 \pm 0.62$ \\
\hline$\left[\mathrm{C}_{8} \mathrm{C}_{8} \mathrm{im}\right]\left[\mathrm{NTf}_{2}\right]$ & 1.1948 & $1.5800 \pm 0.0021$ & $1.8878 \pm 0.0025$ & $906.36 \pm 1.23$ \\
\hline$\left[\mathrm{C}_{9} \mathrm{C}_{9} \mathrm{im}\right]\left[\mathrm{NTf}_{2}\right]$ & 1.1692 & $1.6057 \pm 0.0023$ & $1.8774 \pm 0.0027$ & $966.17 \pm 1.38$ \\
\hline$\left[\mathrm{C}_{10} \mathrm{C}_{10} \mathrm{im}\right]\left[\mathrm{NTf}_{2}\right]$ & 1.1522 & $1.6308 \pm 0.0014$ & $1.8790 \pm 0.0016$ & $1027.00 \pm 0.86$ \\
\hline
\end{tabular}

${ }^{a} C_{p}^{o} / V$ values were calculated taking into account the specific heat capacities, $c_{p}^{o}$, and the experimental density values available in the literature. ${ }^{29}$

specific heat capacities, $c_{p}^{o}$, and the experimental density values available in the literature. ${ }^{29}$ For this series of ionic liquids, no literature data were found. The heat capacities of the studied ionic liquids were measured with an uncertainty of less than $0.15 \%$.

The graphic representations of the molar heat capacity data, $C_{p, m}^{o}$, and the specific heat capacity data, $c_{p}^{o}$, as a function of the total number of carbons atoms in the alkyl side chains of the cation, $N$, are presented in Figure 1.

Unlike to what it was observed for the series of ionic liquids, $\left[\mathrm{C}_{\mathrm{N}-1} \mathrm{C}_{1} \mathrm{im}\right]\left[\mathrm{NTf}_{2}\right]$ (asymmetric ILs) ${ }^{20}$, the $C_{p, m}^{o}$ $(T=298.15 \mathrm{~K})$ of the $\left[\mathrm{C}_{\mathrm{N} / 2} \mathrm{C}_{\mathrm{N} / 2} \mathrm{im}\right]\left[\mathrm{NTf}_{2}\right]$ series (symmetric ILs) increases near linearly along the alkyl chain length, with a contribution of $(30.88 \pm 0.09) \mathrm{J} \mathrm{K}^{-1} \mathrm{~mol}^{-1}$ per methylene group $\left(-\mathrm{CH}_{2}-\right)$.

From Figure 1(I) it can be observed that, for the same total number of carbons in the alkyl chains, the symmetric series presents slightly lower molar heat capacities than the asymmetric ones, being this difference larger above $\left[\mathrm{C}_{6} \mathrm{C}_{1} \mathrm{im}\right]\left[\mathrm{NTf}_{2}\right]$. This difference becomes more evident in the specific heat capacities, presented in Figure 1(II), where the asymmetric ionic liquids present higher specific heat capacities than the symmetric. Instead of two regions in the $c_{p}^{o}$ values, as observed for the asymmetric series, the specific heat capacities of the symmetric ionic liquids could be described by a curvilinear function with a decrease of the derivative, without a clear distinction of two regions with a discontinuity of a derivative. The contribution per $-\mathrm{CH}_{2}-$ group for the $c_{p}^{o}$ values is higher for the symmetric ILs with shorter alkyl side chains, reaching a region where a subtle decrease in the $-\mathrm{CH}_{2}-$ group contribution is observed, with a clear odd-even effect for longer alkyl side chains, as depicted in Figure 1(II).

Figure 2 presents the volumic heat capacities against the total number of carbons in the alkyl side chains of the cation. In this graphic representation it is clear that the symmetric imidazolium based ionic liquids present lower volumic heat capacities than those observed for the asymmetric ILs. $^{20}$ For the asymmetric ionic liquids, ${ }^{20}$ the volumic heat capacity reaches a constant value $\left(1.92 \mathrm{~J} \mathrm{~K}^{-1} \mathrm{~cm}^{-3}\right)$ above $\left[\mathrm{C}_{6} \mathrm{C}_{1} \mathrm{im}\right]\left[\mathrm{NTf}_{2}\right]$ (Figure 2 "Region B" in the asymmetric series). In the case of the symmetric series, the volumic heat capacities present an identical decrease in the volumic heat capacities, from $\left[\mathrm{C}_{2} \mathrm{C}_{2} \mathrm{im}\right]\left[\mathrm{NTf}_{2}\right]$ to $\left[\mathrm{C}_{6} \mathrm{C}_{6} \mathrm{im}\right]\left[\mathrm{NTf}_{2}\right]$, reaching a constant value of $1.88 \mathrm{~J} \mathrm{~K}^{-1} \mathrm{~cm}^{-3}$ (Figure 2 "Region $\mathrm{B}$ " in the symmetric series) significantly lower than the observed value for the asymmetric ILs from $\left[\mathrm{C}_{7} \mathrm{C}_{7} \mathrm{im}\right]\left[\mathrm{NTf}_{2}\right]$ to $\left[\mathrm{C}_{10} \mathrm{C}_{10} \mathrm{im}\right]\left[\mathrm{NTf}_{2}\right]$. The lower constant value for the volumic

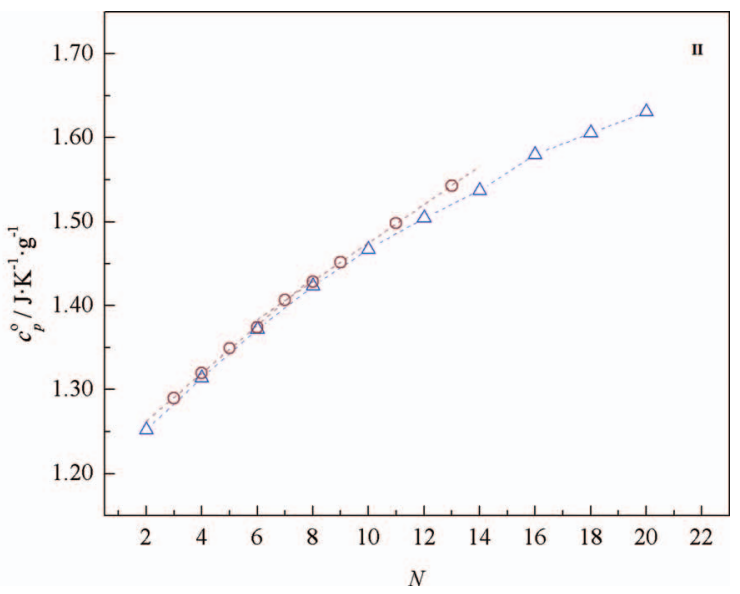

FIG. 1. Molar heat capacities (I) and specific heat capacities (II) as a function of the total number of carbon atoms in the alkyl side chains of the cation. Graph (I) $\bigcirc$ (gray), $\left[\mathrm{C}_{\mathrm{N}-1} \mathrm{C}_{1} \mathrm{im}\right]\left[\mathrm{NTf}_{2}\right]\left(\mathrm{N}=3-9,11\right.$, and 13); ${ }^{20}-$ (gray), fitting of $C_{p, m}^{o}$ values of $\left[\mathrm{C}_{3} \mathrm{C}_{1}\right.$ im] $\left[\mathrm{NTf}_{2}\right]-\left[\mathrm{C}_{5} \mathrm{C}_{1}\right.$ im] $\left[\mathrm{NTf}_{2}\right]$; - $(\mathrm{gray})$, fitting of $C_{p, m}^{o}$ values of $\left[\mathrm{C}_{7} \mathrm{C}_{1} \mathrm{im}\right]\left[\mathrm{NTf}_{2}\right]-\left[\mathrm{C}_{12} \mathrm{C}_{1} \mathrm{im}\right]\left[\mathrm{NTf}_{2}\right] ; \Delta$ (blue), $\left[\mathrm{C}_{\mathrm{N} / 2} \mathrm{C}_{\mathrm{N} / 2} \mathrm{im}\right]\left[\mathrm{NTf}_{2}\right](\mathrm{N}=2,4,6,8,10,12,14,16,18,20)$; --- (blue), fitting of $C_{p, m}^{o}$ values of $\left[\mathrm{C}_{1} \mathrm{C}_{1} \mathrm{im}\right]\left[\mathrm{NTf}_{2}\right]-\left[\mathrm{C}_{10} \mathrm{C}_{10} \mathrm{im}\right]\left[\mathrm{NTf}_{2}\right]$. Graph (II) $\bigcirc$ (gray), [ $\left.\mathrm{C}_{\mathrm{N}-1} \mathrm{C}_{1} \mathrm{im}\right]\left[\mathrm{NTf}_{2}\right],{ }^{20} \Delta$ (blue), $\left[\mathrm{C}_{\mathrm{N} / 2} \mathrm{C}_{\mathrm{N} / 2} \mathrm{im}\right]\left[\mathrm{NTf}_{2}\right]$. 


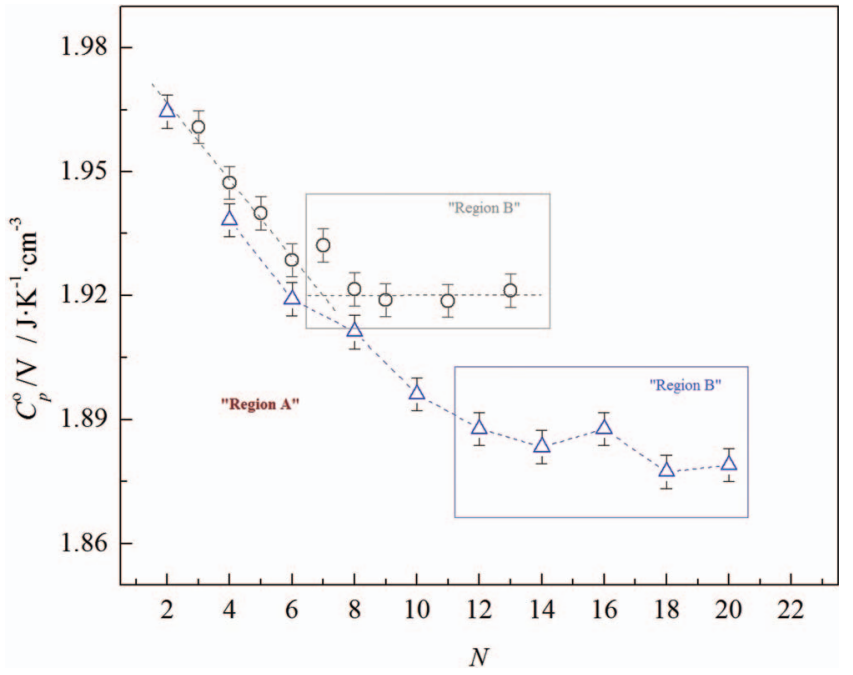

FIG. 2. Volumic heat capacities as a function of the total number of carbon atoms in the alkyl side chains of the cation. $\bigcirc$ (gray), $\left[\mathrm{C}_{\mathrm{N}-1} \mathrm{C}_{1}\right.$ im] $\left.] \mathrm{NTf}_{2}\right](\mathrm{N}$ $=3-9,11$, and 13); ${ }^{20} \triangle$ (blue), $\left[\mathrm{C}_{\mathrm{N} / 2} \mathrm{C}_{\mathrm{N} / 2} \mathrm{im}\right]\left[\mathrm{NTf}_{2}\right](\mathrm{N}=2,4,6,8,10,12$, $14,16,18,20)$.

heat capacity obtained for the symmetric series is related with the higher separations between the ions in the charged region, due to the high steric hindrance arising from the alkyl chains present in both sides of the cation. This lowers the contribution for the heat capacity of the alkyl chain located in the charged region more significantly than in the asymmetrical ILs.

The observed trend shift in the volumic heat capacities at $\left[\mathrm{C}_{6} \mathrm{C}_{6} \mathrm{im}\right]\left[\mathrm{NTf}_{2}\right]$ is in good agreement with the trend shift previously found in the viscosity data. ${ }^{29}$ Moreover, the volumic heat capacities result from $\left[\mathrm{C}_{2} \mathrm{C}_{2} \mathrm{im}\right]\left[\mathrm{NTf}_{2}\right]$ to $\left[\mathrm{C}_{10} \mathrm{C}_{10} \mathrm{im}\right]\left[\mathrm{NTf}_{2}\right]$ show a differentiation with a visible oddeven effect with higher $C_{p}^{o} / V$ for the even numbered ionic liquids, $\left[\mathrm{C}_{2} \mathrm{C}_{2} \mathrm{im}\right]\left[\mathrm{NTf}_{2}\right],\left[\mathrm{C}_{4} \mathrm{C}_{4} \mathrm{im}\right]\left[\mathrm{NTf}_{2}\right],\left[\mathrm{C}_{6} \mathrm{C}_{6} \mathrm{im}\right]\left[\mathrm{NTf}_{2}\right]$, $\left[\mathrm{C}_{8} \mathrm{C}_{8} \mathrm{im}\right]\left[\mathrm{NTf}_{2}\right]$, and $\left[\mathrm{C}_{10} \mathrm{C}_{10} \mathrm{im}\right]\left[\mathrm{NTf}_{2}\right]$. The higher values of $C_{p}^{o} / V$ of the even numbered ionic liquids are related with the some lower vibrational frequencies modes of the ionic liquids, and are in qualitative agreement with their lower cohesive energies and higher liquid absolute entropy derived previously from the thermodynamic properties of vaporization obtained for the $\left[\mathrm{C}_{\mathrm{N} / 2} \mathrm{C}_{\mathrm{N} / 2} \mathrm{im}\right]\left[\mathrm{NTf}_{2}\right](\mathrm{N}=4,6,8,10,12) .{ }^{30}$

The decrease in the $C_{p}^{o} / V$ from $\left[\mathrm{C}_{1} \mathrm{C}_{1} \mathrm{im}\right]\left[\mathrm{NTf}_{2}\right]$ to $\left[\mathrm{C}_{6} \mathrm{C}_{6} \mathrm{im}\right]\left[\mathrm{NTf}_{2}\right]$ is mainly due to the decrease of the ionic liquid densities along the alkyl chain length of the cation. ${ }^{29}$ The observed constant value for the $C_{p}^{o} / V$ for the heavier symmetrical ionic liquids probably results from a balance between the decrease of the density and the increase of the contribution per methylene group, $-\mathrm{CH}_{2}-$, in the volumic heat capacities. The profile of the two regions (Figure 2, "Region A," "Region B"), found for the heat capacity data for the extended series of $\left[\mathrm{C}_{\mathrm{N} / 2} \mathrm{C}_{\mathrm{N} / 2} \mathrm{im}\right]\left[\mathrm{NTf}_{2}\right]$, is in agreement with the expected effect arising from the nanostructuration in ionic liquids. ${ }^{20}$ The constant value of $C_{p}^{o} / V$ (Figure 2), reached after $\left[\mathrm{C}_{6} \mathrm{C}_{6} \mathrm{im}\right]\left[\mathrm{NTf}_{2}\right]$ ("Region B"), indicates that the volumic heat capacity of the $-\mathrm{CH}_{2}-$ group remains unchanged in agreement with the expected behaviour of continuous non-polar segregated region.
It is well established that in the liquid phase of ionic liquids, the polar regions tend to organize themselves in order to enhance the electrostatic interactions between the cation and anion and the alkyl chains of the cation for a non-polar segregated network. ${ }^{13,14,19}$ In previous studies, the experimental evidence for the nanostructuration in ionic liquids was verified to occur above $\left[\mathrm{C}_{6} \mathrm{C}_{1} \mathrm{im}\right]\left[\mathrm{NTf}_{2}\right] .^{20,21,29}$ Based on the results obtained in the present work, we found a clear indication that for the symmetric series, $\left[\mathrm{C}_{\mathrm{N} / 2} \mathrm{C}_{\mathrm{N} / 2} \mathrm{im}\right]\left[\mathrm{NTf}_{2}\right]$, the limit for the beginning of the nanostructuration/alkyl chain segregation is around $\left[\mathrm{C}_{6} \mathrm{C}_{6} \mathrm{im}\right]\left[\mathrm{NTf}_{2}\right]$.

\section{ACKNOWLEDGMENTS}

Thanks are due to Fundação para a Ciência e Tecnologia (FCT), Lisbon, Portugal and to FEDER for financial support to Centro de Investigação em Química, University of Porto through the project Pest-C/QUI/UI0081/2011, and CICECO, University of Aveiro, through the project Pest-C/CTM/LA0011/2011. Marisa A. A. Rocha acknowledges the financial support from FCT and the European Social Fund (ESF) under the Community Support Framework (CSF) for the award of a Ph.D. Research Grant No. SFRH/BD/60513/2009.

${ }^{1}$ Heat Capacities: Liquids, Solutions and Vapours, edited by E. Wilhelm and T. M. Letcher (The Royal Society of Chemistry, Cambridge, UK, 2010).

${ }^{2}$ M. Zábranský, Z. Kolskaá, V. Růžička, Jr., and E. S. Domalski, J. Phys. Chem. Ref. Data 39, 013103 (2010).

${ }^{3}$ M. Zábranský, V. Růžička, Jr., and E. S. Domalski, J. Phys. Chem. Ref. Data 30, 1199 (2001).

${ }^{4}$ Y. U. Paulechka, J. Phys. Chem. Ref. Data 39, 033108 (2010).

${ }^{5}$ J. M. P. França, C. A. Nieto de Castro, M. M. Lopes, and V. M. B. Nunes, J. Chem. Eng. Data 54, 2569 (2009).

${ }^{6}$ V. V. Chaban and O. V. Prezhdo, J. Phys. Chem. Lett. 4, 1423 (2013).

${ }^{7}$ Ionic Liquids in Synthesis, edited by P. Wasserscheid and T. Welton, (Wiley-VCH Verlag GmbH, Weinheim, Germany, 2007).

${ }^{8}$ Ionic Liquids, edited by B. Kirchner (Springer, Berlin, 2010).

${ }^{9}$ Ionic Liquids-New Aspects for the Future, edited by J.-I. Kadokawa (InTech, 2013).

${ }^{10}$ S. M. Urahata and M. C. C. Ribeiro, J. Chem. Phys. 122, 024511 (2005).

${ }^{11}$ Y. Wang and G. A. Voth, J. Am. Chem. Soc. 127, 12192 (2005).

${ }^{12}$ S. Izvekov and G. A. Voth, J. Chem. Phys. 123, 134105 (2005).

${ }^{13}$ J. N. A. Canongia Lopes and A. A. H. Pádua, J. Phys. Chem. B 110, 3330 (2006).

${ }^{14}$ M. F. C. Gomes, J. N. C. Lopes and A. A. H. Padua, Top. Curr. Chem. 290, 161 (2010).

${ }^{15}$ A. Triolo, O. Russina, H.-J. Bleif and E. Di Cola, J. Phys. Chem. B 111, 4641 (2007).

${ }^{16}$ O. Russina, A. Triolo, L. Gontrani, R. Caminiti, D. Xiao, L. G. Hines, Jr., R. A. Bartsch, E. L. Quitevis, N. Pleckhova and K. R. Seddon, J. Phys.: Condens. Matter 21, 424121 (2009).

${ }^{17}$ A. Triolo, O. Russina, B. Fazio, G. B. Appetecchi, M. Carewska, and S. Passerini, J. Chem. Phys. 130, 164521 (2009).

${ }^{18}$ O. Russina, A. Triolo, L. Gontrani, and R. Caminiti, J. Phys. Chem. Lett. 3, 27 (2012).

${ }^{19}$ K. Shimizu, M. F. C. Gomes, A. A. H. Pádua, L. P. N. Rebelo, and J. N. Canongia Lopes, J. Mol. Struct.: THEOCHEM 946, 70 (2010).

${ }^{20}$ M. A. A. Rocha, M. Bastos, J. A. P. Coutinho, and L. M. N. B. F. Santos, J. Chem. Thermodyn. 53, 140 (2012).

${ }^{21}$ M. A. A. Rocha, C. F. R. A. C. Lima, L. R. Gomes, B. Schröder, J. A. P. Coutinho, I. M. Marrucho, J. M. S. S. Esperança, L. P. N. Rebelo, K. Shimizu, J. N. C. Lopes, and L. M. N. B. F. Santos, J. Phys. Chem. B 115, 10919 (2011).

${ }^{22}$ J. Konicek, J. Suurkuusk, and J. Wadsö, Chem. Scr. 1, 217 (1971).

${ }^{23}$ J. Suurkuusk and I. Wadsö, J. Chem. Thermodyn. 6, 667 (1974). 
${ }^{24}$ L. M. N. B. F. Santos, M. A. A. Rocha, A. S. M. C. Rodrigues, V. Štejfa, M. Fulem, and M. Bastos, J. Chem. Thermodyn. 43, 1818 (2011).

${ }^{25}$ R. Sabbah, A. Xu-wu, J. S. Chickos, M. L. P. Leitão, M. V. Roux, and L. A. Torres, Thermochim. Acta 331, 93 (1999).

${ }^{26}$ R. D. Chirico, V. Diky, J. W. Magee, M. Frenkel, and K. N. Marsh, Pure Appl. Chem. 81, 791 (2009).

${ }^{27}$ M. E. Wieser and T. B. Coplen, Pure Appl. Chem. 83, 359 (2011).
${ }^{28}$ M. E. Wieser and M. Berglund, Pure Appl. Chem. 81, 2131 (2009).

${ }^{29}$ M. A. A. Rocha, C. M. S. S. Neves, M. G. Freire, O. Russina, A. Triolo, J. A. P. Coutinho, and L. M. N. B. F. Santos, "Alkylimidazolium Based Ionic Liquids: Impact of Cation Symmetry on Their Nanoscale Structural Organization," J. Phys. Chem. B (published online).

${ }^{30}$ M. A. A. Rocha, J. A. P. Coutinho, and L. M. N. B. F. Santos, J. Phys. Chem. B 116, 10922 (2012) 